\title{
NEWSPAPERS OF THE KYIV GENERAL GOVERNORATE AT THE BEGINNING OF THE XX CENTURY: LANGUAGE, CIRCULATION, PERIODICITY OF PUBLICATION
}

\author{
Oleksandr Tyshkevych \\ National Academy of Culture and Arts Management \\ 9 Lavrsk str., Kyiv, Ukraine, 01015 \\ panstrooper@gmail.com
}

Abstract

The article represents the Ukrainian-language newspapers of the Kyiv General Governorate of the early XX century and defines their role in the socio-political life of that time. It should be noted, that out of more than 100 publications, only 9 were in Ukrainian. Despite constant persecution by the tsarist administration, Ukrainian-language newspapers covered all aspects of Ukrainian life under the rule of the Russian Empire. Ukrainian-language newspapers monitored the development of society and the influenced on the formation of the national consciousness of ethnic Ukrainians.

The object of the research is aspects of the political life of Ukrainians on the pages of publications: "Hromadska Dumka", "Rada", "Borot'ba", "Slovo", "Selo", "Zasiv", "Mayak", "Svitova Zirnytsia." The mentioned newspapers were published in different periods, but are a valuable source for studying the history of Ukraine at the beginning of the XX century.

The purpose of the article is to study the political orientation, the language of publications, and the frequency of Ukrainian-language newspapers in the Kyiv General Governorate in the early $\mathrm{XX}$ century.

By summing up the role of newspapers of the Kyiv General Governorate at the beginning of the XX century, it should be noted, that out of more than 100 publications, published in the Volyn Governorate, Kyiv Governorate, Podil Governorate, only 8 were Ukrainian-language. Nevertheless, despite constant persecution by the tsarist administration, the newspapers reflected all aspects of Ukrainian life under the control of the Russian Empire. Newspaper publications reflected the life of the Ukrainian community while influencing the formation of the national identity of ethnic Ukrainians [1]. It seems that no issue of Ukrainian national life has escaped their pages. Even the slightest manifestation of the cultural or political life of Ukrainians under the government of the Russian Empire found a response in the pages of publications in "Hromadska Dumka", "Rada", "Borot'ba", "Slovo", "Selo", "Zasiv", "Mayak", "Svitova Zirnytsia." Although the mentioned newspapers were published in different periods, they are a valuable source for studying the history of Ukraine in the early XX century, testify to the growth of national and cultural revival of the Ukrainian people in Russian Ukraine.

The study can be applied to prepare students and graduates in the field of Historical Sciences and Culturology.

The newspapers of the Kyiv General Governorate (Volyn, Kyiv, and Podil Governorate) of the early XX century were researched and systematized by language, circulation, and frequency of publication for the first time.

The study can be the basis for further research of the Ukrainian periodicals for the period from 1800 to 1861 of the XIX century.

Keywords: newspapers, Kyiv General Governorate, Hromadska Dumka, Rada, Borot'ba, Slovo, Selo, Zasiv, Mayak, Svitova Zirnytsia, Zhoda, Volyn Governorate, Kyiv Governorate, Podil Governorate.

DOI: 10.21303/2504-5571.2020.001565

\section{Introduction}

The object of the research is aspects of the political life of Ukrainians on the pages of publications: "Hromadska Dumka" [2], "Rada" [3], "Borot'ba" [4], "Slovo" [4], "Selo" [5], "Zasiv" [7], "Mayak" [8], "Svitova Zirnytsia" [6]. The mentioned newspapers were published in different pe- 
riods, but are a valuable source for studying the history of Ukraine at the beginning of the XX century.

Until 1905, the publication of newspapers on the territory of the Kyiv General Governorate was impossible. The mentioned fact was based on the Valuev's Circular of July 20, 1863, which forbade the printing of books and periodicals in Ukrainian, as well as the Ems decree - the order of Russian Emperor Alexander II from 18 (30) May 1876, signed in the Ems Ukaz, which supplemented by the Valuev's Circular [9]. Tsarism closely guarded its monopoly on periodicals, hence for a long time in the Russian province, which included the Southwestern Territory of the Russian Empire, only official government publications and government departmental periodicals such as "Kyiv Provincial Information", "Volyn Provincial" and "Podolsk Provincial Gazette" were.

The purpose of the article is to study the political orientation, the language of publications, and the frequency of Ukrainian-language newspapers in the Kyiv General Governorate in the early XX century; to analyze recent research and publications. V. Ignatienko in the biographical index, which covers the period from 1816 to 1916, noted the list of newspapers and magazines, published in Ukrainian. The index is based on the ethnographic-territorial principle [10]. A. Zhyvotko studied the development of the periodical press on the territory of the Kyiv General Governorate [10].

The first months of the revolution of 1905-1907 showed that it was impossible to deal with the one by punitive means only. Therefore, the ruling circles of Russia "began to talk about the need for some renewal of the existing state system" [11, p. 40]. Nicholas II of Russia "was forced to go for it" [11, p. 40]. In August 1905 he signed the "Manifesto on the Establishment of the State Duma, which was to become a legislative foundation that did not shake the grounds of the autocracy and was formed in the same undemocratic way" [11, p. 40]. However, due to the active boycott, organized by the revolutionary forces, the Duma elections did not take place. The popular movement intensified, and in October 1905 a temporary balance of fighting forces was established in the country. "The autocracy was not able to speak openly against the revolution. The revolution did not have the strength to strike a decisive blow at tsarism" [11, p. 40]. In such conditions, "a combination of ruling circles from repression to concessions was inevitable" [11, p. 40]. The October Manifesto (October 17, 1905) became such a forced concession.

The revolution and October Manifesto greatly eased the situation of the periodical press in the Russian Empire. In October-November 1905 censorship was abolished [11, p. 40]. Formally, the main department for the press and its local bodies continued to exist, but were afraid to interfere in publishing [11, p.192].

On November 24, 1905, a Personal Supreme Decree to the Governing Senate on Provisional Rules on Occasional Publications was issued, in which it was noted, that "by the Manifesto of October 17 of this year, we made the government responsible for fulfilling our unshakable will to give the population the unshakable foundations of civil freedom, one of the conditions of which is freedom of speech" [11, p.194].

The temporary rules for the printing of November 24, 1905 "limited freedom of the press, in comparison with pre-revolutionary legislation, ones became a significant step forward on the way to a democratic society" [11, p. 193]. The rules abolished previous censorship for all periodicals, published in the cities, removed administrative penalties, and deprived the Minister of the Interior of the right to prohibit discussions in the press on any issue; the rules on pledges for periodicals and some other restrictions were abolished [11, p.193].

During this period, the following newspapers continued to be published on the territory of the Kyiv General Governorate:

- in the Volyn Governorate: "Volynskie Gubernskie Vedomosti", "Volyn" (Zhytomyr);

- in the Kyiv Governorate (Kyiv): "Kievskie Gubernskie Vedomosti”, "Kievlianin”, "Kievskoe Slovo", "Telegramy", "Kievskaya Gazeta”, "Kievskie Otkliki”, "Sputnik Sredney Schkoly i Eksterna"; - in the Podil Governorate: "Podiskie Gubernskie Vedomosti" (Kamianets-Podilskyi).

After the proclamation of the new rules for printing on November 24, 1905, the following newspapers began to be published in Kyiv:

- "Vecheniaya Gazeta". The only issue was released on December 21. By order of the General Governorate, the publication was suspended for the entire period of martial law for "harmful direction"; 
- "Kievskaya Gazeta". In 1905 under the number of the newspaper (No. 284-291) telegrams of "Kievskaya Gazeta", devoted to strikes, was published;

- "Kievskie Novosti";

_ "Yuzhnaya Nedelia", by order of the head of the region from 02.12 .1905 the publication was closed;

- "Hromadska Dumka" was the first Ukrainian-language newspaper of the Kyiv General Governorate, the first issue of which was published on December 31, 1905.

The research aims to study the political orientation, the language of publications, and the frequency of Ukrainian-language newspapers in the Kyiv Governorate of the early XX century.

\section{Materials and Methods}

By investigating publications in newspapers that reflected the life of the Ukrainian community, which influenced the formation of the national identity of ethnic Ukrainians, general scientific methods and techniques were applied: information collection method, descriptive method, structural analysis, classification method, as well as the performance of the historical-logical method of data analysis to disclose a retrospective analysis of the political orientation of newspapers.

\section{Result}

On the territory of the Kyiv General Governorate in 1861-1914, newspapers were published in the Volyn Governorate, in the cities of Volodymyr-Volynskyi, Zhytomyr, Kremenets, and Pochaiv). In the Kyiv Governorate - Berdychiv, Kaniv, Kyiv, Uman, Cherkasy. In the Podil Governorate - Balta, Vinnytsia, Kamianets-Podilskyi, Mogilev (Podilskyi) and the village of Pankivka. The center of newspaper operations in the Kyiv General Governorate was Kyiv, which published the largest number of newspapers, especially after the revolution of 1905-1907.

Thus, in 1905, 15 newspapers were published in Kyiv and 16 in the Kyiv Governorate (Table 1).

Table 1

Publishing of newspapers for a year in Kyiv (1906-1914)

\begin{tabular}{cc}
\hline Date of Publishing & Number of Newspapers \\
\hline 1906 & 29 out of 29 \\
1907 & 17 out of 18 \\
1908 & 17 out of 17 \\
1909 & 18 out of 18 \\
1910 & 20 out of 21 \\
1911 & 24 out of 26 \\
1912 & 20 out of 21 \\
1913 & 19 out of 21 \\
1914 & 15 out of 22
\end{tabular}

A particular state of affairs can be explained not only by the fact that Kyiv was a central city of the Kyiv Governorate province and the center of the Kyiv General Governorate. Kyiv was, first of all, the ancient center of the socio-political and cultural life of the Ukrainian lands, which were part of the Russian Empire. Kyiv was a center, where scientific, cultural, and artistic personnel were concentrated; it became the center of the revolutionary movement, the center of the national revival of sub-Russian Ukraine [12].

It is not possible to establish the total number of newspapers that were published on the territory of the Kyiv General Governorate in the period from February 19, 1861, to the beginning of the First World War. Furthermore, it is not about the diligence of researchers. The fact is that the researchers did not seek to do the mentioned studies. The reason for the mentioned issue is the lack of surviving to this day, albeit small, but still separate numbers of newspapers. It often happened that the newspaper, which had just been published, had already been confiscated by the police. 
Some newspapers were only typed and could not be printed. It should also be noted, that different directories provide different numbers of newspapers, published in the Kyiv General Governorate. The most complete collection of newspaper collections today is presented in the Department of Periodicals of the Vernadsky National Library of Ukraine [13]. The previously mentioned funds represent the most complete collection of newspapers, published in the Kyiv General Governorate in 1861-1914. According to our estimates, in different periods on the territory of the Kyiv General Governorate in 1861-1914 almost 113 newspapers were published.

Out of the total number of newspapers, published in the Kyiv General Governorate, only 8 newspapers were Ukrainian-language, such as "Hromadska Dumka" (1905-1906), "Borot'ba" (1906), "Rada" (1907-1914), “Slovo" (1907-1909), "Selo” (1909-1911), “Zasiv” (1911-1912), "Svitova Zirnytsia” (1906-1913), "Mayak” (1912-1914).

According to the frequency of newspapers, they are placed as follows (Table 2).

Table 2

Frequency of newspapers

\begin{tabular}{cc}
\hline Frequency of release & Number \\
\hline Daily & 59 \\
Three times a week & 9 \\
Twice or three times a week & 1 \\
Twice a week & 5 \\
Weekly & 2 \\
Twice a month & 2 \\
Monthly & 1 \\
Twice a day & 2 \\
Irregular and without definition & 10 \\
Illustrated applications (weekly) & 5
\end{tabular}

According to the frequency, Ukrainian-language newspapers are published as follows (Table 3).

Table 3

Frequency of Ukrainian-language newspapers

\begin{tabular}{cc}
\hline Ukrainian-language newspapers & Number \\
\hline Daily & 2 \\
Twice a week & 1 \\
Weekly & 5
\end{tabular}

In particular, the following were daily: "Hromadska Dumka" and "Rada"; "Borot'ba" was published twice a week, as well as "Slovo", "Selo", "Zasiv", "Svitova Zirnytsia" and "Mayak" were published weekly.

In terms of all the newspapers of the Kyiv General Governorate, Ukrainian-language newspapers were ranked as follows (Table 4).

Table 4

Political orientation of newspapers

\begin{tabular}{cc}
\hline Political orientation (according to the content) & Number \\
Party & 1 \\
Political, economic, and literary & 3 \\
Folk illustrated newspapers for peasants and workers & 2 \\
For the peasant and working intelligentsia & 1 \\
Peasant newspapers & 1 \\
\hline
\end{tabular}

In particular, the party newspaper was the weekly newspaper "Slovo", the central publication of the Ukrainian Party of Social Democrats. Political, economic, and literary include "Hro- 
madska Dumka", "Borot'ba", and "Rada". The popular illustrated newspapers for peasants and workers were "Selo", "Zasiv". The newspaper for the peasant and working intelligentsia was the "Mayak" and the peasant newspaper - "Svitova Zirnytsia".

As already mentioned above, it became possible to publish newspapers in the Ukrainian language in the Kyiv General Governorate after the proclamation of new rules for printing on November 24, 1905 [14]. It should be noted, that a characteristic feature of the publication of Ukrainian-language newspapers in sub-Russian Ukraine is that 50-100 \% of Ukrainian-language newspapers were published in the Kyiv General Governorate and 90-100 \% in Kyiv.

The research proves that the study of newspapers is a valuable source for analyzing the history of Ukraine of the early XX century and is evidence of the growth of national and cultural revival of the Ukrainian nation.

\section{Conclusions}

By summarizing the role of newspapers of the Kyiv General Governorate in the early XX century, it should be noted, that among more than 100 publications, published in the Volyn Governorate, Kyiv Governorate, Podil Governorate, only 8 were Ukrainian-language. Nevertheless, despite constant persecution by the tsarist administration, the newspapers reflected all aspects of Ukrainian life under the control of the Russian Empire.

Newspaper publications reflected the life of the Ukrainian community while influencing the formation of the national identity of ethnic Ukrainians. It seems that no issue of Ukrainian national life has escaped their pages. Even the slightest manifestation of the cultural or political life of Ukrainians under the government of the Russian Empire found a response in the pages of publications: "Hromadska Dumka", "Rada", "Borot'ba", "Slovo", "Selo", “Zasiv", "Mayak", "Svitova Zirnytsia." Although the mentioned newspapers were published in different periods, the ones are a valuable source for studying the history of Ukraine in the early twentieth century, testify to the growth of national and cultural revival of the Ukrainian people in Russian Ukraine.

\section{References}

[1] Afonina, O. S., Herchanivska, P. E., Denysiuk, Zh. Z., Diachuk, V. P. et. al. (2019). Cultural and arts studies of national academy of culture and arts management. Lviv-Toruń: Liha-Pres, 252.

[2] Hromadianska dumka (1905). Available at: http://irbis-nbuv.gov.ua/dlib/item/0001090

[3] Rada (1906). Available at: http://irbis-nbuv.gov.ua/dlib/item/0001110

[4] Borotba (1906). Available at: http://irbis-nbuv.gov.ua/dlib/item/0002385

[5] Slovo (1907).

[6] Zhyvotko, A. P. (1999). Istoriia ukrainskoi presy. Kyiv: Nasha kultura i nauka, 368.

[7] Zasiv (1911)

[8] Maiak. (1912). Available at: https://uk.wikipedia.org/wiki/Маяк_(тижневик)

[9] Lemke, M. (1904). Epokha tsenzurnykh reform 1859-1865 godov. Saint Petersburg, 540.

[10] Ihnatenko, V. (1930). Bibliohrafiia ukrainskoi presy (1816-1916). Kharkiv: Derzhvydav Ukrainy, 288.

[11] Chistiakov, O. I. (1994). Rossiiskoe zakonodatelstvo X - XX vekov. Vol. 9. Epokha burzhuazno-demokraticheskikh revoliutsii. Moscow, 352.

[12] Shemshuchenko, Yu. S. ta in. (Eds.) (1999). Yurydychna entsyklopediia. Vol. 2: D-Y. Kyiv: Ukr. entsykl. im. M. P. Bazhana, 2744.

[13] Polonska-Vasylenko, N. (1995). Istoriia Ukrainy. Vol. 2. Vid seredyny XVII stolittia do 1923 roku. Kyiv: Lybid, 608.

[14] Istoriia ukrainskoi dozhovtnevoi presy (1983). Lviv: Vyshcha shkola, 511. 